cemoti $\begin{aligned} & \text { Cahiers d'études sur la Méditerranée } \\ & \text { orientale et le monde turco-iranien }\end{aligned}$

38 | 2006

Islam au Caucase

Le Daghestan : islam populaire et islam radical

Frédérique LONGUET-MARX

Q OpenEdition

Journals

Édition électronique

URL : http://journals.openedition.org/cemoti/1538

DOI : 10.4000/cemoti. 1538

ISSN : $1777-5396$

Éditeur

AFEMOTI

Édition imprimée

Date de publication : 20 février 2006

ISSN : 0764-9878

Référence électronique

Frédérique LONGUET-MARX, «Le Daghestan : islam populaire et islam radical », Cahiers d'études sur la Méditerranée orientale et le monde turco-iranien [En ligne], 38 | 2006, mis en ligne le 13 février 2006, consulté le 08 septembre 2020. URL : http://journals.openedition.org/cemoti/1538 ; DOI : https:// doi.org/10.4000/cemoti.1538

Ce document a été généré automatiquement le 8 septembre 2020

Tous droits réservés 


\section{Le Daghestan : islam populaire et islam radical}

Frédérique LONGUET-MARX

\section{RÉSUMÉS}

De tradition soufie, l'islam revêt aujourd'hui des formes diverses - et parfois nouvelles - au Caucase du Nord-Est. Les confréries n'agissent plus dans l'opposition comme à l'époque soviétique mais font partie des instances officielles. L'islam populaire se développe avec un accroissement très sensible du nombre des cheikhs. Les lieux d'enseignement et de prière se multiplient. Le "wahhabisme ", forme d'islam radical, se développe réellement au Daghestan au milieu des années 1980. Il est interdit depuis 1999 mais les attentats d'origine à la fois mafieuse et politico-religieuse sont quasi quotidiens. La zone de conflit ne semble plus circonscrite à la Tchétchénie et on peut se poser aujourd'hui la question d'un embrasement général dans l'ensemble de ces petites Républiques du Caucase du Nord. 